\title{
Anaphylaxis associated with exercise
}

\author{
George Du Toit \\ From Food Allergy and Anaphylaxis Meeting 2011 \\ Venice, Italy. 17-19 February 2011
}

Exercise-induced Anaphylaxis (EIA) is a rare, unpredictable, potentially fatal, syndrome characterised by anaphylaxis associated with exercise. Anaphylaxis is associated with a mortality rate of between $1-2 \%$; importantly, some $5-15 \%$ of anaphylactic episodes are caused by /or are associated with exercise. EIA may occur independently of food allergen ingestion, or may require the ingestion of a food allergen around the time of exercise, known as Food-dependent exercise-induced anaphylaxis (FDEIA). Concomitant medication use may also be required as an additional facilitating factor, known as 'summation anaphylaxis'. There are now more than one hundred reviews on the topic of EIA (food dependent and non-food dependent) upon which much of our current knowledge of the condition is based. The aim of this presentation is to draw on key clinical features of these conditions; we will then either support, or challenge, existing hypotheses with respect to exerciseinduced pathophysiological mechanisms that may underlie EIA. This will be in the context of recent advances in our understanding of exercise physiology.

Published: 12 August 2011

Submit your next manuscript to BioMed Central and take full advantage of:

- Convenient online submission

- Thorough peer review

- No space constraints or color figure charges

- Immediate publication on acceptance

- Inclusion in PubMed, CAS, Scopus and Google Scholar

- Research which is freely available for redistribution

\section{Biomed Central}

